\title{
Glacier Retreat in Doda Valley, Zanskar Basin, Jammu \& Kashmir, India
}

\author{
Praveen Kumar Rai ${ }^{1, *}$, M.S.Nathawat ${ }^{2}$, Kshitij Mohan ${ }^{3}$ \\ ${ }^{1}$ (PGDRS \& GIS), Department of Geography, Banaras Hindu University, Varanasi, Uttar Pradesh, India \\ ${ }^{2}$ Department of Geography, School of Science, IGNOU, New Delhi, India \\ ${ }^{3}$ Department of Geography, Banaras Hindu University, Varanasi, Uttar Pradesh, India \\ *Corresponding Author: rai.vns82@gmail.com
}

Copyright (C) 2013 Horizon Research Publishing All rights reserved.

\begin{abstract}
Glacier monitoring is important to provide estimates of freshwater storage in Himalayan region. Therefore, understanding the spatio-temporal glacier retreat is important for utilization of the Himalayan water resource. The study area covers Dodavalley, Zanskar basin in Jammu \& Kashmir. An attempt is also made here to analyze the glacier retreat and morphometric parameters like, length, width, area, area accumulation ratio (AAR), specific mass balance etc., of the glaciers using multi-temporal satellite data of IRS-1C LISS III of August 2001, Landsat of 1975, 1992 and 2002and in conjunction with Survey of India (SOI) topographical map of 1962 and United State of Geological Survey (USGS) map of 1925. In this study, it was found that, total glacier area loss from 1962 to 2001 is $18.16 \%$. Though in the years 1975 and 1992, there is positive specific mass balance but in the year 2001, specific mass balance of all glaciers was negative.
\end{abstract}

Keywords Glacier, Himalayas, Remote Sensing, Glacier Inventory, Glacier Retreat, AAR Etc

\section{Introduction}

The Himalaya, the youngest and fragile mountain system of the earth, has direct influence on climate control, regional hydrology and environment of our subcontinent. About 17\% of its mountain area is covered by glaciers (Dobhal et al., 1999). Fresh water resources in the Himalayas are stored in the form of glaciers. Change in climate directly affects glacier mass and thereby, the water resources. Melting from snow bound areas during the summer forms an important source of many perennial rivers originating in the higher Himalaya. Most of the glaciers in the mountain region of the Himalayas have receded subsequently during the last century, in response to climatic warming. Recent studies have shown wide-scale retreat of glaciers not only in the Himalayas but also in Alps, Andes and Rocky mountains (Kulkarni et al., 2002). Investigation carried out in the Himalaya suggests that almost all glaciers are retreating and annual rate of retreat is varying from 16 to $35 \mathrm{~m}$ (Dobhal et al., 1999). Optical multispectral space borne imaging represents a well-established satellite remote sensing method for mapping and monitoring glaciers and their retreat. Remote sensing techniques using satellite optical stereo data combined with multispectral images would enable the computation of accurate DTMs for glacier morphometric characterization (Bahuguna et al., 2003). Morphometric analysis of the glaciers is an essential requirement to evaluate the nature of changes in glacier dimensions and also to establish relationship between climatic change and dynamics of glaciers (Kulkarni et al., 2002). In the Indian Himalaya, glaciers cover approximately $23,000 \mathrm{sq} \mathrm{km}$ of area and have one of the largest concentrations of glacier-stored water outside the Polar Regions. Change in climate directly affects glacier mass and thereby, the water resources. Melting from snow-bound areas during summers forms an important source of water for many perennial rivers originating in the higher Himalaya (Dobhal et al., 1999). Further, acceleration in worldwide glacier mass loss over the last few decades has significant implications in terms of global sea level rise. The glacial terrain being very difficult to have access to and limitations of conventional methods of mapping, remote sensing data plays a crucial role in glacial domain mapping (Praveen et. al, 2009). Optical range bands give good registrations of glaciers in remote sensing data.

In the present study authors attempted to analyze glacier retreat over 13 selected glaciers and its morphometric characteristics in the Doda valley of part of Zanskar basin based on multi temporal satellite data acquired during the years 1975, 1992, and 2001 and topographical maps of the years 1925 and 1962. Similar such studies on glaciers using remote sensing data were carried out by Dozier and Hall (1987) using remote sensing data. In Indian Himalayas Kulkarni et al., (2002 \& 2005) carried out studies using remote sensing data on various aspects of glacial retreat.

\section{Study Area}


The present study cover a part of Doda valley $\left(32^{\circ} 59^{\prime} 19.98^{\prime \prime} \mathrm{N}\right.$ to $33^{\circ} 55^{\prime} 6.32^{\prime \prime} \mathrm{N}$ latitude and $76^{\circ} 15^{\prime} 4.13^{\prime \prime} \mathrm{E}$ to $77^{\circ} 15^{\prime} 32.76^{\prime \prime} \mathrm{E}$ longitude), in Zanskar mountain ranges, Ladakh, Jammu \& Kashmir covering about 2088 sq. km area (Figure 1). Its elevation ranges from 3071- $6401 \mathrm{~m}$ above msl. The highest relief areas are located in the south western parts where as the lowest relief areas are found in north eastern parts of the Doda valley. In the winters starting from mid-October and usually continuing till May, almost all parts of the valley are covered with a thick layer of snow. Throughout winter the temperature is around $-20^{\circ}$ centigrade in Zanskar valley. The summer season begins in May and it becomes warm fairly quickly. The summer season lasts relatively longer till August than in other parts of Ladakh. No tree covers exist on mountainous slope although good crop flourish in the wide valley of Padam area during summer season.

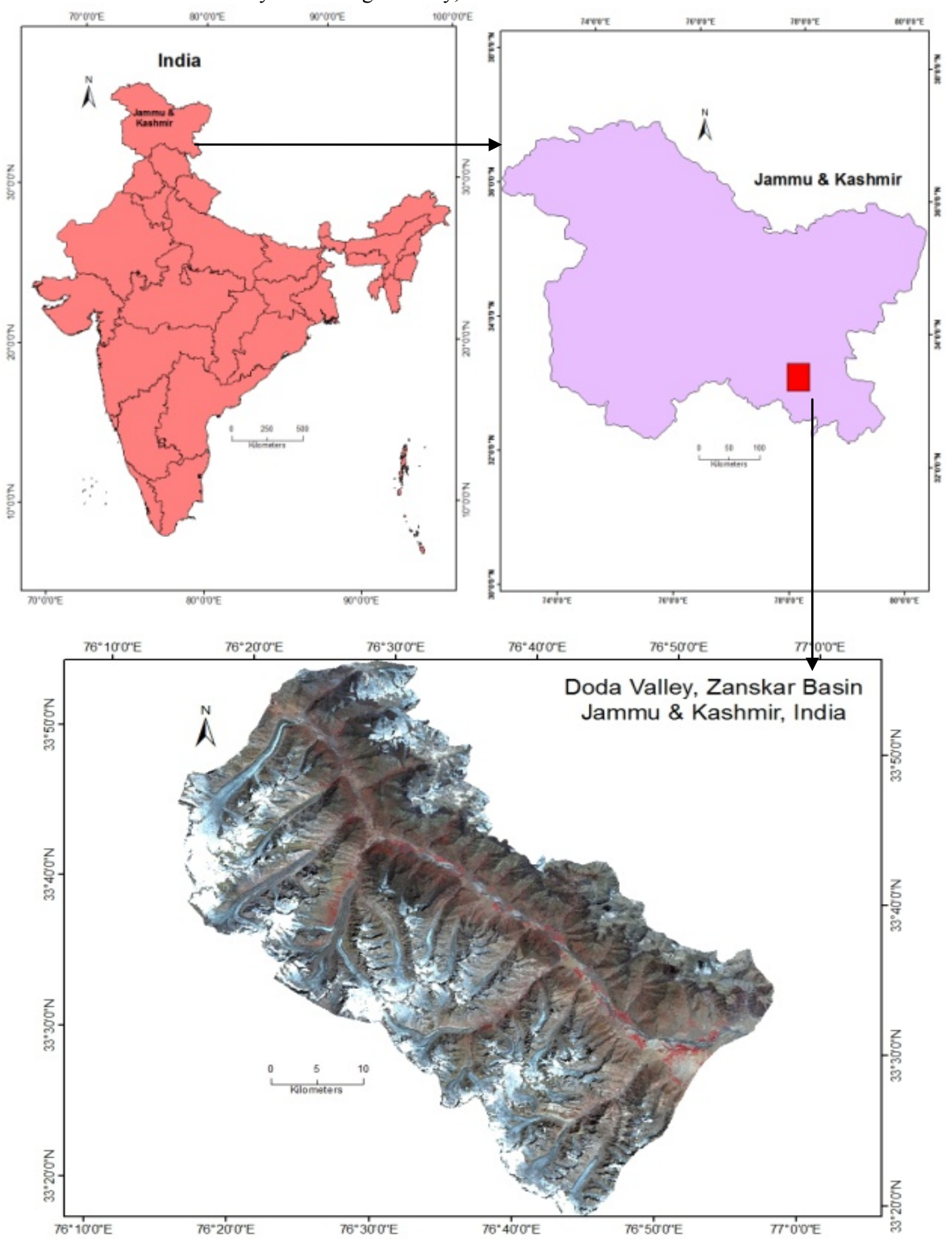

Figure 1. Location of the study area as viewed on the IRS-1C LISS III satellite data 
In geological terms, the Doda valley is a young land, formed only a few million years ago by the buckling and folding of the earth's crust as the Indian sub-continent pushed with irresistible force against the immovable mass of Asia.In the study area various geological formations are well exposed due to no vegetation cover of the rock formations. The meta sedimentary formation exhibit well developed bedding planes, folding and faulting.

The study area is a part of higher Himalayan Mountains and possesses a variety of slopes ranging from very gentle to steep slopes. The development of slopes largely depends on the rock composition, structure and the geomorphic processes operating in the region. The general slope of the study area is from northeast to southwest. Slope within all the glaciers of the study area generally range between $5^{\circ}-15^{\circ}$. Doda and Zanskar are the main rivers in the study area. The direction of flow of Doda river is from northwest to southeast and it confluence with Zanskar river in south-eastern part of the study area at Padam.

\section{Data Source \& Methodology}

Digital Remote Sensing data of October 1975 (Landsat MSS), September 1992 (Landsat TM), September 2002 (Landsat ETM+), August 2001 (IRS-1C LISS III) and Shuttle Radar Topographic Mission (SRTM) Data along with Survey of India topographical maps on 1:50,000 scale of 1962 and 1:2,50,000 USGS map of 1925, are used for the study. Data sets of August-October were selected as snow cover during this period is usually at its minimum and the glacier areas are fully exposed.

Landsat data (MSS of Year 1975, TM of 1992, ETM+ of 2002) are downloaded through internet, which were already georeferenced. IRS-1C LISS-III satellite data of 2001 is geometrically rectified on the basis of collected ground control points by global positioning (GPS) during field visit and also with the help of georeferenced Landsat satellite data. SOI and USGS topographical maps are also rectified with the help georeferenced satellite data.

In the present study 13 glaciers in the Doda valley having distinct accumulation and ablation zones with well delineated boundaries in all the satellite images were taken up for studying the spatio-temporal retreat of glacier. Initially, boundaries of various glaciers were mapped using topographical map from Survey of India and subsequently by using satellite images of different time periods covering the area.

The oldest information about extent of the glaciers in the study area is extracted from USGS topographical map of 1925.The digital elevation model was generated using SRTM data. The generation of digital terrain model (DTMs) by draping false color composite over DEM helped in visualizing glacial processes and in glacier mapping from ablation to accumulation zones (Figure 2). Band ratioing using Normalized Difference Snow Index (NDSI) and ratio of TM 4 / TM 5 bands was used to delineate glacier area on Landsat TM. The ratio TM-4/TM-5 effectively separate ice and snow zones over glacier surfaces, particularly in areas containing shadow (Dozier et al. 1987) and to enhance contrast in the snow zones (Paul, F., 1999). Normalized Difference Snow Index (NDSI) was effective in distinguishing snow from similarly bright soil and rock, as well as from clouds in TM imagery (Dozier et al., 1987). Flowchart of methodology is shown in the figure 3.

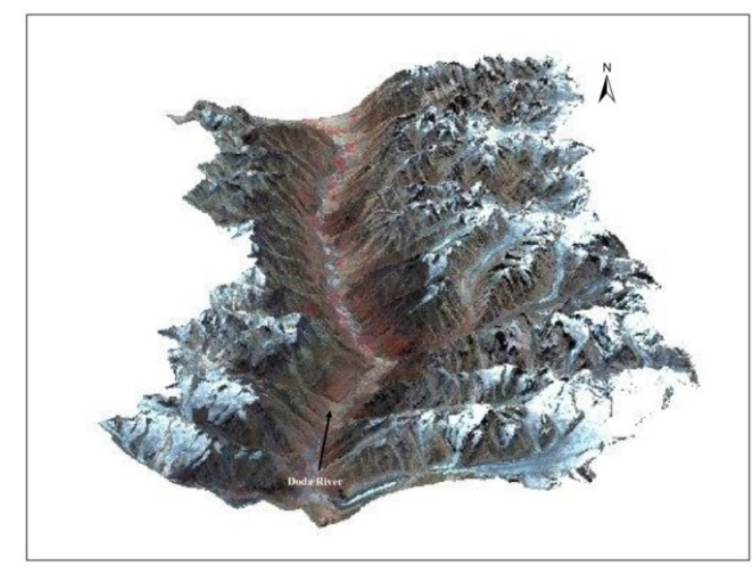

Figure 2. Digital Terrain Model (DTM's) of the study area for perspective view 


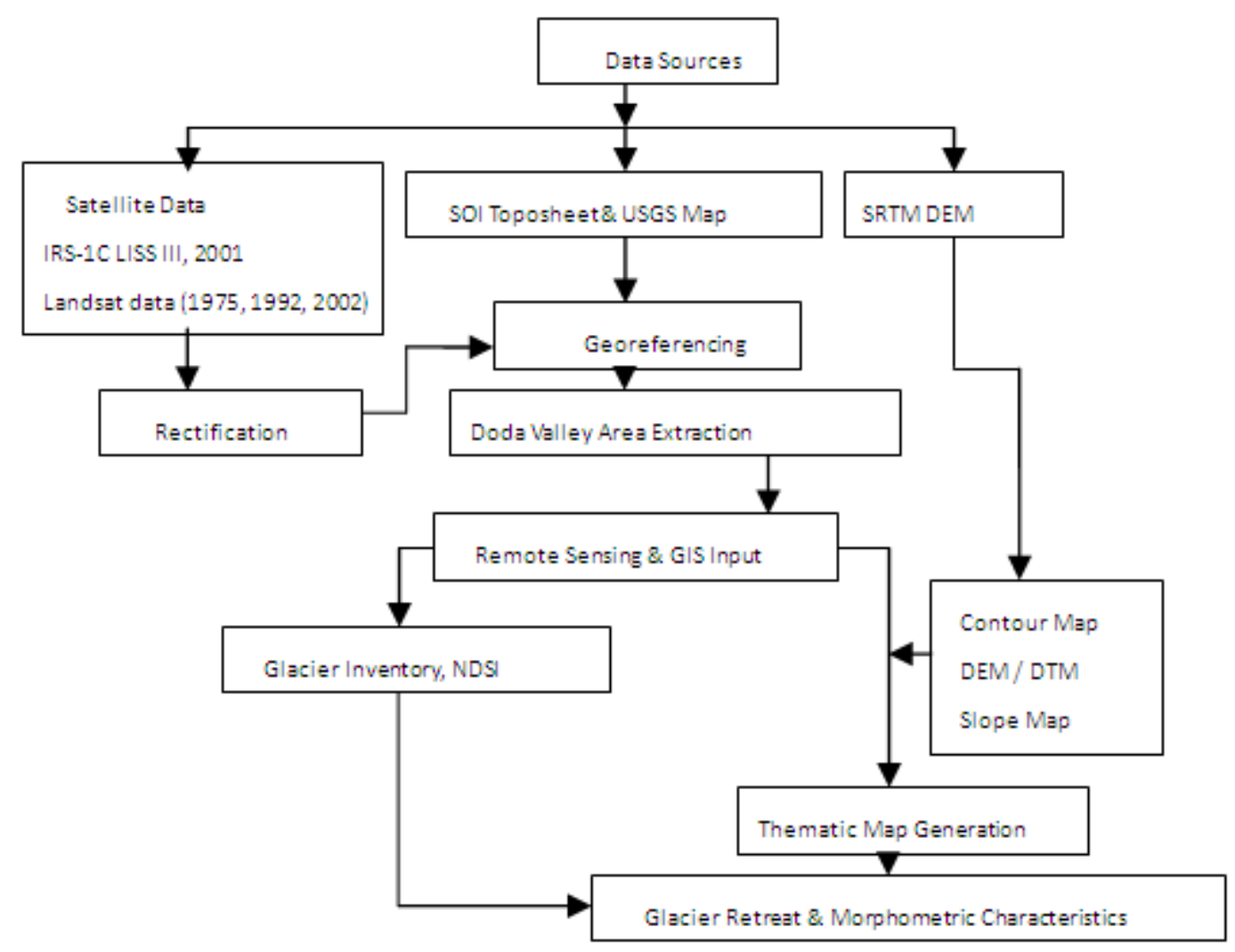

Figure 3. Flowchart of methodology

Normalized Difference Snow Index (NDSI) was generated with bands 2 and 5 (of Landsat ETM+) and the resultant image with excellent differentiation was used to digitize glacier boundaries (Figure 4).

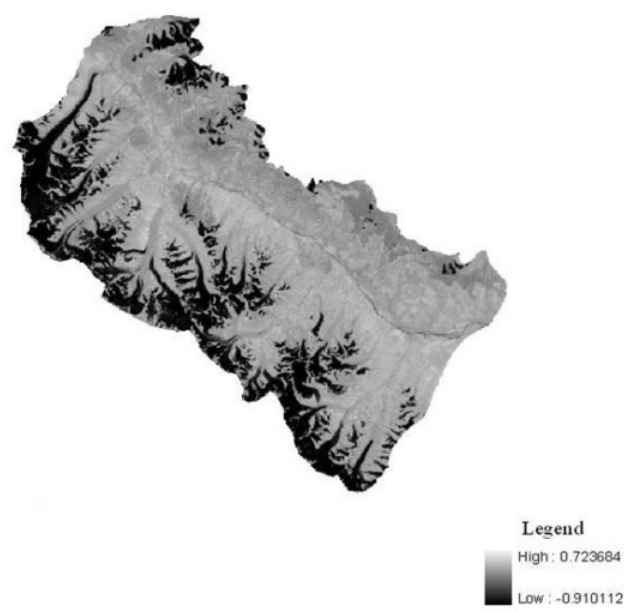

Figure 4. Normalized Difference Snow Index (NDSI) of the Doda Vally, Zanskar Basin, Jammu \& Kashmir

It is calculated using the formula, NDSI= (TM2- TM5)/ (TM2+TM5).

The standard false color composite (FCC's) using TM 2, 3 and 4 bands (BGR) was not sufficient for snow cover type mapping because of its spectral saturation in these two bands. The colour composite using bands 4,5 and 7 helped in discriminating glacier features and the landforms (Bolch et al.,2005). A reconnaissance field survey was done in the study area during July 2007 to delineate various glacier landforms in the area. Position of some of the glacier snouts in Doda valley were recorded with a hand held GPS during field survey. Snouts of glaciers are delineated by identifying origin of stream from the frontal part of the glaciers on the visual interpretation of satellite data. Field photographs at different location of Doda valley showing snout position of glaciers and terminus characteristic is shown in the plate 1 . 

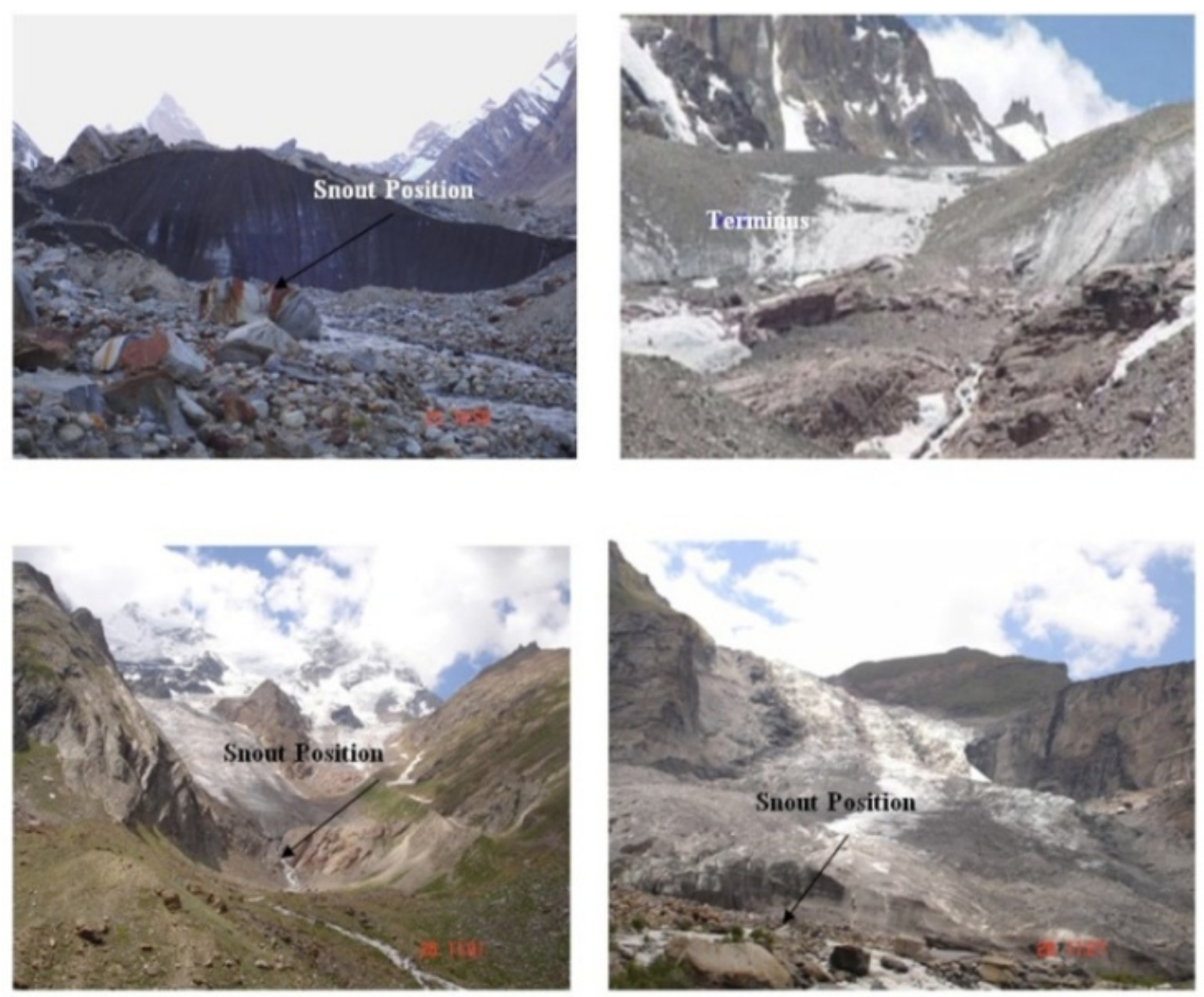

Plate 1. Field photographs at different location of Doda valley showing snout position of glaciers

\section{Result \&Discussion}

\subsection{Glacier Area Loss (Absolute Changes in Glacier Area)}

Glacier G1 is the longest glacier of the Doda valley having a length of $23.66 \mathrm{~km}$, a width of $1.17 \mathrm{~km}$ with a total area of about $64.51 \mathrm{sq}$. km. Glacier G6, G9 and G11 are the smallest glacier of the valley (lengths of 5 to $6 \mathrm{~km}$ ) whereas other glaciers having lengths of about $7 \mathrm{~km}$. to $9 \mathrm{~km}$. The changes in glaciers areal extent from the year 1962 onwards are given in table 1. During 1992 to 2001 glacier G4 shows maximum change in the glacier area (11.97 sq.km.) but in the period 1962 to 1975 and 1975 to 1992 it shows only 1.67 sq.km. \& $2.36 \mathrm{sq} . \mathrm{km}$. of total change in the glacier area respectively and glacier G6 shows minimum change in the glacier area (0.66 sq.km.) between years 1992 to 2001 .

Loss in the glacier area is also estimated. The total loss of each glacier extent was observed from 1962 to 2001 . The glacier G5 \& G3 shown $30.48 \%$ and $28.91 \%$ of the area loss respectively. Total area loss from 1962 to 2001 is $18.16 \%$, area loss from 1962 to 1975 is $2.47 \%$, from 1975 to 1992 is $5.77 \%$ and from 1992 to 2001 is $10.94 \%$. Details are given in Table 2. It was found that due to shrinkage in glacier area few glaciers have been fragmented from its tributary glaciers. This has resulted in reduction in the total glacier extent but conversely increases in the number of glaciers.

Table 1. Change in the glacier area from 1962 to 2001

\begin{tabular}{|cccc|}
\hline Glacier & \multicolumn{3}{c|}{ Change in area (sq. km.) } \\
\cline { 2 - 4 } Gode & $1962-1975$ & $1975-1992$ & $1992-2001$ \\
\hline G2 & 1.78 & 1.36 & 4.59 \\
\hline G3 & 1.59 & 3.26 & 0.74 \\
\hline G4 & 2.22 & 3.31 & 4.4 \\
\hline G5 & 1.67 & 2.36 & 11.97 \\
\hline G6 & 0.68 & 1.86 & 2.52 \\
\hline G7 & 0.1 & 0.27 & 0.66 \\
\hline G8 & 1.51 & 0.15 & 1.14 \\
\hline G9 & 0.85 & 1.95 & 3.88 \\
\hline G10 & 0.98 & 1.26 & 2.19 \\
\hline G11 & 0.44 & 3.92 & 2.38 \\
\hline G12 & 0.23 & 0.31 & 0.97 \\
\hline G13 & 0.21 & 0.32 & 2.6 \\
\hline
\end{tabular}


Table 2.Percentage loss in the glacier area

\begin{tabular}{|c|c|c|c|c|c|}
\hline \multirow[b]{2}{*}{ lacier Code } & \multicolumn{3}{|c|}{ Glacier Area (sq. km) } & \multirow[b]{2}{*}{ Snout Location } & \multirow{2}{*}{$\begin{array}{c}\text { Altitude of the snout } \\
\text { from } \\
\mathrm{msl}(\mathrm{m})\end{array}$} \\
\hline & 1962 & 2001 & Loss $\%$ & & \\
\hline G1 & 72.24 & 64.51 & 10.700 & $\begin{array}{l}76^{\circ} 22^{\prime} 53.75^{\prime \prime} \mathrm{E} \\
33^{\circ} 50^{\prime} 45.62^{\prime \prime} \mathrm{N}\end{array}$ & 4090 \\
\hline G2 & 22.18 & 16.59 & 25.20 & $\begin{array}{l}76^{\circ} 24^{\prime} 57.05^{\prime \prime} \mathrm{E} \\
33^{\circ} 45^{\prime} 56.64^{\prime \prime} \mathrm{N}\end{array}$ & 4200 \\
\hline G3 & 34.34 & 24.41 & 28.91 & $\begin{array}{c}76^{\circ} 25^{\prime} 5.67^{\prime \prime} \mathrm{E} \\
33^{\circ} 42^{\prime} 21.48^{\prime \prime} \mathrm{N}\end{array}$ & 4025 \\
\hline G4 & 75.00 & 59.00 & 21.333 & $\begin{array}{l}76^{\circ} 27^{\prime} 48.02^{\prime \prime} \mathrm{E} \\
33^{\circ} 40^{\prime} 1.59^{\prime \prime} \mathrm{N}\end{array}$ & 3950 \\
\hline G5 & 16.60 & 11.54 & 30.48 & $\begin{array}{l}76^{\circ} 30^{\prime} 32.43^{\prime \prime} \mathrm{E} \\
33^{\circ} 37^{\prime} 29.35^{\prime \prime} \mathrm{N}\end{array}$ & 4620 \\
\hline G6 & 4.95 & 3.92 & 20.80 & $\begin{array}{l}76^{\circ} 33^{\prime} 32.53^{\prime \prime} \mathrm{E} \\
33^{\circ} 37^{\prime} 34.54^{\prime \prime} \mathrm{N}\end{array}$ & 4825 \\
\hline G7 & 8.16 & 6.80 & 16.66 & $\begin{array}{c}76^{\circ} 35^{\prime} 1.31^{\prime \prime} \mathrm{E} \\
33^{\circ} 36^{\prime} 45.47^{\prime \prime} \mathrm{N}\end{array}$ & 4290 \\
\hline G8 & 30.63 & 23.29 & 23.96 & $\begin{array}{c}76^{\circ} 35^{\prime} 7.94^{\prime \prime} \mathrm{E} \\
33^{\circ} 30^{\prime} 43.06^{\prime \prime} \mathrm{N}\end{array}$ & 4580 \\
\hline G9 & 16.71 & 12.41 & 25.73 & $\begin{array}{l}76^{\circ} 36^{\prime} 23.62^{\prime \prime} \mathrm{E} \\
33^{\circ} 28^{\prime} 18.65^{\prime \prime} \mathrm{N}\end{array}$ & 4580 \\
\hline G10 & 35.91 & 28.63 & 20.27 & $\begin{array}{l}76^{\circ} 41^{\prime} 58.63^{\prime \prime} \mathrm{E} \\
33^{\circ} 25^{\prime} 9.82^{\prime \prime} \mathrm{N}\end{array}$ & 4570 \\
\hline G11 & 6.77 & 5.05 & 25.40 & $\begin{array}{l}76^{\circ} 42^{\prime} 15.17^{\prime \prime} \mathrm{E} \\
33^{\circ} 30^{\prime} 26.92^{\prime \prime} \mathrm{N}\end{array}$ & 4800 \\
\hline G12 & 24.40 & 21.25 & 12.90 & $\begin{array}{l}76^{\circ} 43^{\prime} 31.70^{\prime \prime} \mathrm{E} \\
33^{\circ} 24^{\prime} 21.94^{\prime \prime} \mathrm{N}\end{array}$ & 4250 \\
\hline G13 & 15.47 & 13.83 & 10.60 & $\begin{array}{c}76^{\circ} 46^{\prime} 1.13^{\prime \prime} \mathrm{E} \\
33^{\circ} 23^{\prime} 47.57^{\prime \prime} \mathrm{N}\end{array}$ & 4580 \\
\hline
\end{tabular}

\subsection{Changes in the Snout Elevation}

Change in the snout elevation reflects the dynamic processes operating in the snout region of the glacier (Rai et al. 2012). To evaluate the shift in snout position during observation periods the elevation contours over the glacier were generated using Digital Elevation Model (DEMs) available from satellite data of Shuttle Radar Topographic
Mission (SRTM). The elevation changes in the snout position between 1962 and 2001 were determined by elevation profiling along the centerline of the glacier. The glacier G3 shows significant elevation changes in snout position by $55 \mathrm{~m}$ which was $3970 \mathrm{~m}$ in 1962 and became $4025 \mathrm{~m}$ in 2001, while glacier G2 shows $50 \mathrm{~m}$ in elevation change from 1962 to 2001 (Table.3).

Table 3. Total change in snout elevation from 1962 to 2001

\begin{tabular}{|cccccc|}
\hline Glacier Code & & Elevation (m) & & $\begin{array}{c}\text { Difference in Elevation } \\
\text { (meter) }\end{array}$ & $\begin{array}{c}\text { Total Change in } \\
\text { Elevation from 1962 to } \\
2001 \\
\text { (meter) }\end{array}$ \\
G1 & 2001 & 1992 & 1962 & $2001-1992$ & 20 \\
G2 & 4090 & 4081 & 4070 & 9 & 50 \\
G3 & 4200 & 4165 & 4150 & 35 & 55 \\
G4 & 4025 & 4005 & 3970 & 20 & 35 \\
G5 & 3950 & 3936 & 3915 & 14 & 50 \\
G6 & 4620 & 4590 & 4570 & 30 & 15 \\
G7 & 4825 & 4818 & 4810 & 07 & 46 \\
G8 & 4640 & 4610 & 4594 & 30 & 16 \\
G9 & 4580 & 4576 & 4564 & 04 & 24 \\
G10 & 4580 & 4570 & 4552 & 10 & 18 \\
G11 & 4570 & 4562 & 4552 & 08 & 26 \\
G12 & 4800 & 4788 & 4774 & 12 & 40 \\
G13 & 4250 & 4230 & 4210 & 20 & 25 \\
\hline
\end{tabular}


Table 4. Retreat of 13 selected glaciers in Doda valley

\begin{tabular}{|c|c|c|c|c|c|c|}
\hline \multirow[b]{2}{*}{$\begin{array}{l}\text { Glacier } \\
\text { Code }\end{array}$} & \multicolumn{6}{|c|}{ Retreat (meter) } \\
\hline & $1925-62$ & $\begin{array}{c}1962- \\
1975\end{array}$ & $\begin{array}{c}1975- \\
1992\end{array}$ & $\begin{array}{l}1992- \\
2001\end{array}$ & $\begin{array}{l}\text { Retreat } \\
(1962- \\
2001) \\
\end{array}$ & Retreat/Year \\
\hline G1 & 1232 & 173 & 146 & 425 & 745 & 18.0 \\
\hline G2 & 1332 & 194 & 258 & 888 & 1341 & 33.0 \\
\hline G3 & 1965 & 260 & 282 & 284 & 827 & 20.6 \\
\hline G4 & 920 & 255 & 355 & 278 & 888 & 22.0 \\
\hline G5 & 1161 & 276 & 334 & 155 & 766 & 19.0 \\
\hline G6 & 1832 & 81 & 39 & 122 & 243 & 6.0 \\
\hline G7 & 1365 & 335 & 185 & 255 & 776 & 19.0 \\
\hline G8 & $\begin{array}{c}\text { Glacier } \\
\text { Boundary Are } \\
\text { Not Available }\end{array}$ & 214.93 & 133 & 258 & 607 & 15.0 \\
\hline G9 & 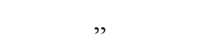 & 148 & 265 & 153 & 567 & 14.0 \\
\hline G10 & 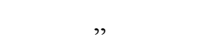 & 118 & 179 & 261 & 559 & 13.9 \\
\hline G11 & ” & 141 & 204 & 226 & 573 & 14.0 \\
\hline G12 & ” & 248 & 172 & 515 & 936 & 23.0 \\
\hline G13 & 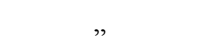 & 138 & 349 & 389 & 878 & 21.0 \\
\hline
\end{tabular}

\subsection{Retreat of Glacier Snout}

On satellite images position of snout could be delineated by identifying geomorphic features such as origin of stream from the snout and disposition of end moraines(Kulkarni et al. 2005).SRTM DEM is highly useful in glacier morphometric analysis and evaluating vertical shift in the snout location. Elevation of the each glaciers snouts position during 2001 measured using SRTM DEM derived contours are also given in table 4 . These glacier snouts are mainly located at more than $4000 \mathrm{~m}$ above mean sea level. The contour data can also be used for slope and aspect calculation for evaluating terrain morphologic control on glacier retreat.

Glacier retreat was estimated for all the studied glaciers in the Doda valley based on glacier inventory and snout location derived from 1925 and 1962 topographical maps and 1975, 1992 and 2001 satellite images. Retreats in 13 selected glaciers in the Doda valley are depicted in the plate 10 by draping snout position as recorded in different observation periods on to the 2001 satellite image. Glacier retreat during different time periods of observation is given in Table 4.

Keeping in view, the variability in the duration of the observation periods, per year retreat of each glacier was estimated over a period of 1975 to 2001. Glacier G1, G2, G3, G4, G12 and G13 show retreat at a rate of about $18 \mathrm{~m}, 33 \mathrm{~m}$, $20.6 \mathrm{~m}, 22.0 \mathrm{~m}, 23.0 \mathrm{~m}$ and $21.0 \mathrm{~m}$ per year respectively whereas glacier G6, G10, G9 and G11 are retreating at $6 \mathrm{~m}$, $13.9 \mathrm{~m}, 14.18 \mathrm{~m}$ and $14.32 \mathrm{~m}$ per year respectively. It is estimated that during last 39 years (1962-2001) all glaciers in valley were in a retreating phase. Highest retreat is recorded along G2 $(1.3 \mathrm{~km})$ and G12 $(0.93 \mathrm{~km})$ glacier whereas lowest retreat is recorded along G6 $(0.24 \mathrm{~km}), \mathrm{G} 9(0.56 \mathrm{~km})$ and G10 glacier $(0.55 \mathrm{~km})$. It is to remark in majority of cases smaller glaciers are retreating at lower pace as compared large glaciers. Demarcation of progressive retreat of some of the glaciers during different observation periods as marked on the IRS 1C LISS-III satellite image of 2001 are shown in the figure 5 . 

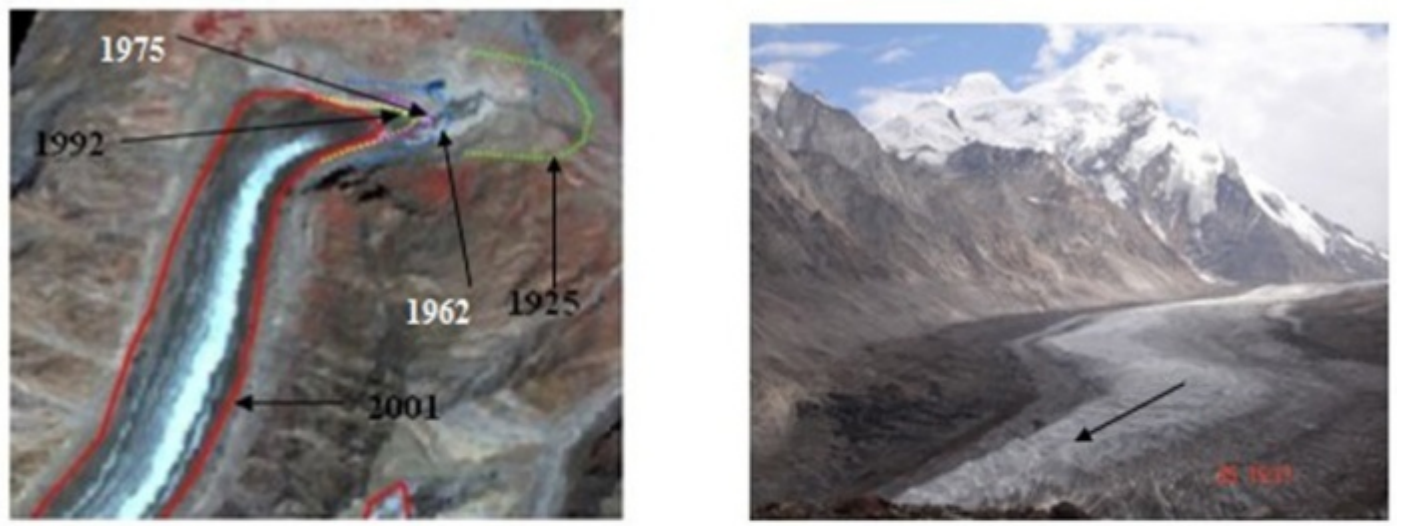

Glacier Gl and its field photograph

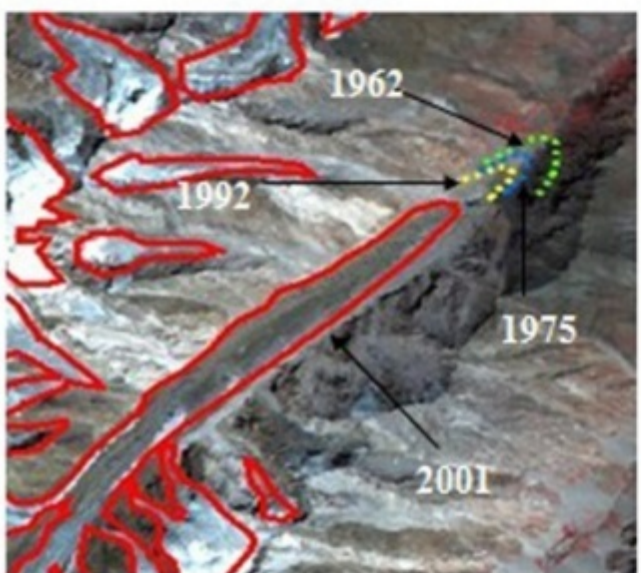

Glacier G2

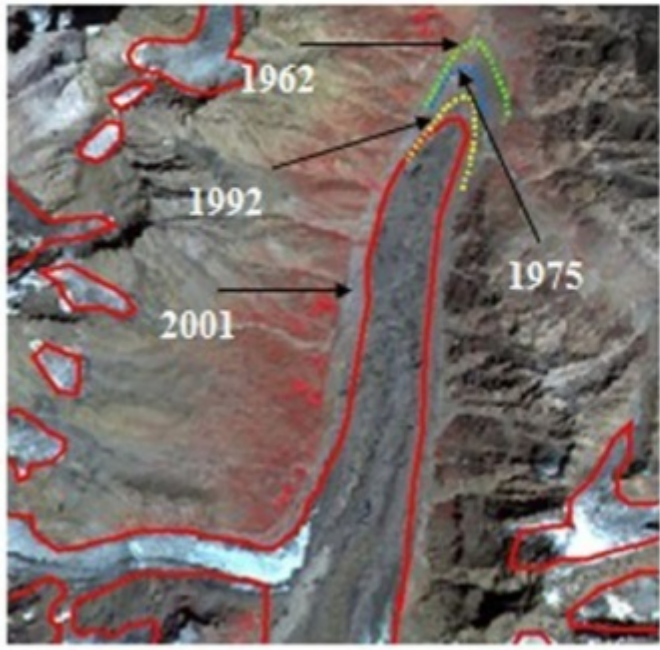

Glacier G4

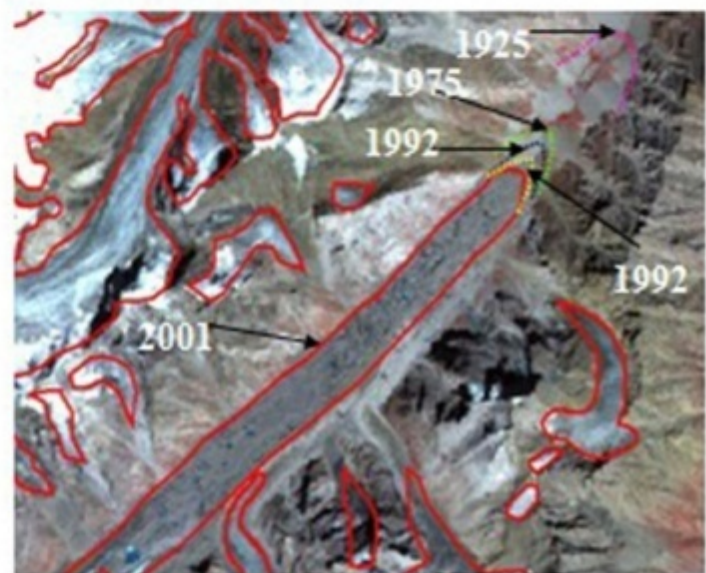

Glacier G3

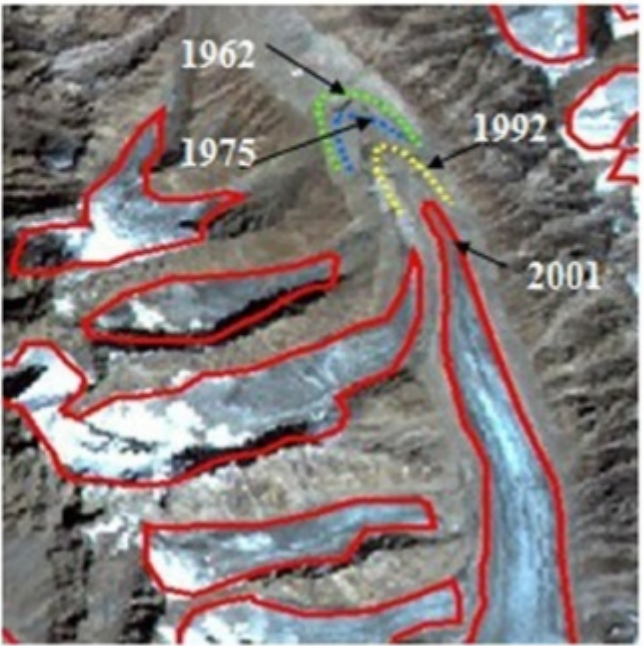

Glacier G5

Figure 5. .Demarcation of progressive retreat of glaciers during different observation periods as marked on the IRS-1C LISS-III satellite image of 2001 
Table 5. Some morphometric parameters of 13 selected glaciers in Doda valley (The three rows for every glacier are for years 2001, 1992 \& 1975 from top to bottom)

\begin{tabular}{|c|c|c|c|c|c|c|c|c|c|c|c|c|}
\hline $\begin{array}{l}\text { Glacier } \\
\text { Code }\end{array}$ & $\begin{array}{l}\text { Length } \\
(\mathrm{m})\end{array}$ & $\begin{array}{l}\text { Average Width } \\
\text { (m) }\end{array}$ & $\begin{array}{c}\text { Area } \\
\text { (sq. km.) }\end{array}$ & $\begin{array}{l}\text { Perimeter } \\
(\mathrm{m})\end{array}$ & $\begin{array}{l}\text { Snout Position } \\
\text { (m) }\end{array}$ & $\begin{array}{c}\text { Transient } \\
\text { Snow Line } \\
\text { Position(m) }\end{array}$ & $\begin{array}{l}\text { Ablation } \\
\text { Area } \\
\text { (sq. km.) }\end{array}$ & $\begin{array}{c}\text { Accumulation } \\
\text { Area } \\
\text { (sq. km.) }\end{array}$ & $\begin{array}{c}\text { AAR } \\
\text { (sq. km.) }\end{array}$ & $\begin{array}{l}\text { AAR } \\
(\%)\end{array}$ & $\begin{array}{l}\text { Thickness } \\
(\mathrm{m})\end{array}$ & $\begin{array}{l}\text { Specific Mass } \\
\text { Balance } \\
(\mathrm{cm})\end{array}$ \\
\hline \multirow{3}{*}{ G1 } & 23663.2 & 1170.51 & 64.51 & 105565.9 & 4090 & 5250 & 33.28 & 31.23 & 0.48 & 48.41 & 174.40 & -3.54 \\
\hline & 24224.9 & 1430.08 & 69.10 & 106286.3 & 4081 & 4675 & 10.06 & 59.04 & 0.854 & 85.44 & 178.27 & 87.44 \\
\hline & 24645.4 & 1566.4 & 70.46 & 107496.8 & 4078 & 4550 & 7.78 & 62.68 & 0.889 & 88.95 & 179.39 & 95.99 \\
\hline \multirow{3}{*}{$\mathrm{G} 2$} & 13103.1 & 811.68 & 16.59 & 63383.89 & 4200 & 5300 & 13.54 & 3.05 & 0.18 & 18.38 & 112.25 & -76.44 \\
\hline & 14102.8 & 1202.11 & 20.33 & 69531.69 & 4165 & 4900 & 6.38 & 10.95 & 0.631 & 63.18 & 113.88 & 33.35 \\
\hline & 15808.6 & 1411.3 & 24.59 & 71550.39 & 4156 & 4820 & 6.27 & 14.32 & 0.695 & 69.54 & 120.53 & 48.82 \\
\hline \multirow{3}{*}{ G3 } & 13657.1 & 778.62 & 24.41 & 54743.55 & 4025 & 5160 & 12.85 & 11.56 & 0.47 & 47.35 & 127.43 & -5.97 \\
\hline & 14307.2 & 880.90 & 28.81 & 65869.71 & 4005 & 4650 & 7.50 & 21.31 & 0.739 & 73.96 & 134.51 & 59.56 \\
\hline & 14714.3 & 971.5 & 32.12 & 79560.58 & 3988 & 4550 & 7.12 & 25.00 & 0.778 & 77.83 & 139.34 & 68.95 \\
\hline \multirow{3}{*}{ G4 } & 14705.5 & 1403.64 & 59.00 & 102991 & 3950 & 5220 & 31.65 & 27.35 & 0.46 & 46.35 & 169.50 & -8.40 \\
\hline & 14886.9 & 912.65 & 70.97 & 107502.1 & 3936 & 4850 & 19.9 & 51.07 & 0.719 & 71.95 & 179.80 & 54.68 \\
\hline & 15460.2 & 998.6 & 73.33 & 108510.5 & 3924 & 4675 & 17.51 & 55.82 & 0.761 & 76.12 & 181.68 & 64.79 \\
\hline \multirow{3}{*}{ G5 } & 9214.01 & 720.09 & 11.54 & 32593.56 & 4620 & 5260 & 7.94 & 3.60 & 0.31 & 31.19 & 99.50 & -44.85 \\
\hline & 9332.47 & 819.6 & 14.06 & 36388.63 & 4590 & 5020 & 3.39 & 10.67 & 0.758 & 75.88 & 106.27 & 64.23 \\
\hline & 9963.4 & 991.7 & 15.92 & 41295.08 & 4578 & 4975 & 2.92 & 13.0 & 0.816 & 81.65 & 110.74 & 78.25 \\
\hline \multirow{3}{*}{ G6 } & 5102.24 & 792.80 & 3.92 & 11997.77 & 4825 & 5260 & 2.72 & 1.20 & 0.30 & 30.61 & 68.84 & -47.28 \\
\hline & 5198.24 & 863.46 & 4.58 & 14985.62 & 4818 & 5300 & 2.68 & 1.90 & 0.414 & 41.48 & 72.67 & 19.37 \\
\hline & 5408.1 & 935.6 & 4.85 & 15292.38 & 4815 & 4260 & 2.44 & 2.41 & 0.496 & 49.69 & 74.130 & 26.60 \\
\hline \multirow{3}{*}{ G7 } & 7459.97 & 2618.42 & 6.80 & 21623.44 & 4290 & 5300 & 3.68 & 3.10 & 0.45 & 45.72 & 83.24 & -10.83 \\
\hline & 7630.53 & 2679.79 & 7.94 & 24804.41 & 4610 & 5160 & 3.14 & 4.80 & 0.604 & 60.45 & 87.749 & 26.72 \\
\hline & 8098.5 & 2794.3 & 8.09 & 23169.68 & 4598 & 4975 & 2.00 & 6.09 & 0.752 & 75.27 & 88.30 & 62.74 \\
\hline \multirow{3}{*}{ G8 } & 8365.86 & 1026.73 & 23.29 & 43890.28 & 4580 & 5140 & 13.45 & 9.84 & 0.42 & 42.24 & 125.49 & -18.12 \\
\hline & 8013.73 & 1102.03 & 27.17 & 47915.33 & 4576 & 4600 & 3.39 & 23.78 & 0.875 & 87.52 & 131.97 & 92.50 \\
\hline & 9357.4 & 1255.6 & 29.12 & 49713.26 & 4570 & 4550 & 2.32 & 26.80 & 0.920 & 92.03 & 134.98 & 103.40 \\
\hline \multirow{3}{*}{ G9 } & 5579.75 & 624.90 & 12.41 & 32849.79 & 4580 & 5320 & 8.60 & 3.81 & 0.30 & 30.70 & 101.95 & -47.28 \\
\hline & 5660.10 & 707.05 & 14.60 & 35685.57 & 4570 & 5280 & 4.07 & 10.53 & 0.721 & 72.12 & 107.61 & 55.07 \\
\hline & 6032.5 & 789.9 & 15.86 & 37657.66 & 4564 & 4900 & 1.93 & 13.93 & 0.878 & 87.83 & 110.60 & 93.25 \\
\hline \multirow{3}{*}{ G10 } & 7685.85 & 1735.15 & 28.63 & 40704.52 & 4570 & 5270 & 17.32 & 11.31 & 0.39 & 39.50 & 134.23 & -25.41 \\
\hline & 7848.46 & 1841.25 & 31.01 & 50100.73 & 4562 & 5200 & 10.46 & 20.55 & 0.662 & 66.26 & 137.76 & 40.85 \\
\hline & 8011.9 & 1933.1 & 34.93 & 54036.73 & 4556 & 4875 & 3.00 & 31.93 & 0.914 & 91.41 & 143.18 & 101.90 \\
\hline \multirow{3}{*}{ G11 } & 5174.14 & 1017.09 & 5.05 & 19066.75 & 4800 & 5360 & 2.69 & 2.36 & 0.46 & 46.73 & 75.17 & -8.40 \\
\hline & 5816.32 & 1352.69 & 6.02 & 24044.69 & 4788 & 5260 & 2.50 & 3.52 & 0.584 & 58.47 & 79.85 & 21.90 \\
\hline & 6148.4 & 1426.5 & 6.33 & 26712.22 & 4780 & 4180 & 2.53 & 3.80 & 0.600 & 60.03 & 81.23 & 25.69 \\
\hline \multirow{3}{*}{ G12 } & 8583.13 & 2665.74 & 21.25 & 40139.28 & 4250 & 5260 & 12.25 & 9.00 & 0.42 & 42.35 & 121.77 & -18.12 \\
\hline & 9085.51 & 2747.51 & 23.85 & 46681.72 & 4230 & 5020 & 7.76 & 16.09 & 0.674 & 67.46 & 126.47 & 43.75 \\
\hline & 9288.9 & 2769.8 & 24.17 & 47387.74 & 4218 & 4930 & 4.60 & 19.57 & 0.809 & 80.96 & 127.02 & 76.57 \\
\hline \multirow{3}{*}{ G13 } & 8737.66 & 1360.86 & 13.83 & 32177.77 & 4580 & 5370 & 8.39 & 5.44 & 0.39 & 39.33 & 105.69 & -25.41 \\
\hline & 9170.12 & 1503.28 & 14.01 & 35633.83 & 4565 & 5200 & 7.24 & 6.77 & 0.483 & 48.32 & 106.14 & 27.58 \\
\hline & 9384.3 & 1595.3 & 15.26 & 42513.65 & 4559 & 4950 & 3.25 & 12.01 & 0.787 & 78.70 & 109.20 & 71.06 \\
\hline
\end{tabular}




\subsection{Morphometry of Glaciers}

Several morphometric parameters including length, width, area, perimeter, orientation etc. were estimated directly. Glacial accumulation area was measured with respect to snow-line altitude. Snow-line altitude was obtained by measuring the distance between the ablation area (where snow-melting is the dominant process) and the accumulation area. Another important parameter called Area Accumulation Ratio (AAR) is a ratio between accumulation area and total glacial area. Specific mass balance is computed using AAR.

In fact, the glacier and snow/ice covered area of the total study area has been divided into 147 glaciers/polygons. The glacier and snow/ice covered area in the total study area has varied in different years/sets of data showing a decreasing areal extent. It was 552.65 sq. $\mathrm{km}$ in 1962 (from SOI Toposheet), 538.96 sq. km. in 1975, 507.82 sq. km. in 1992 and 452.28 sq. $\mathrm{km}$ in 2001. Depth of the glaciers has been calculated using a formula proposed by Kulkarni (1992) and Kulkarni et al., (2004):

$$
\mathrm{H}=-11.32+53.21 \mathrm{~F}^{0.3}
$$

where ' $\mathrm{H}$ ' is the mean glacier thickness ( $m$ ) and ' $F$ ' is the glacier area $\left(\mathrm{km}^{2}\right)$. Specific mass balance of glaciers was calculated implicating AAR in the formula proposed by Kulkarni et al., (op cit):

$$
\mathrm{b}=243.01 * \mathrm{X}-120.187
$$

where ' $b$ ' is the specific mass balance in water equivalent $(\mathrm{cm})$ and ' $\mathrm{X}$ ' the AAR.

The individual morphometric characteristics of the 13 selected glaciers of three time periods of satellite data are presented in Table 5 and a look into the parameters reveal that there are minor to major changes in the linear, areal and volume characteristics of all the glaciers in the study area from 1962 to 2001. Most of the glacier snouts are mainly located at more than $4000 \mathrm{~m}$ above msl. There is general recession of snouts of all the 13 glaciers to various distances. The advancing and retreating snout positions are clearly visible through the presence of terminal moraines. Naithani et al., (2001) have observed that recession of snout is very common to most of the glaciers in the Himalayan region and that the recession is irregular in quantity and time of occurrence. Results indicate that all 13 selected glaciers in this study retreated between 1962 to 2001 as indicated in Table 4.

Transient snow line position of all 13 glaciers has changed from 1975 to 2001. Just for example, transient snow line position of G1 glacier is $5250 \mathrm{~m}$ in 2001 , reduced to $4675 \mathrm{~m}$ and $4550 \mathrm{~m}$ in 1992 and 1975 respectively. Similarly accumulation areas of all the glaciers have reduced between 1975 and 2001.

Accumulation area for each glacier will vary from year to year depending upon the snow-line altitude at the end of the ablation season. Accumulation area of each glacier is reduced from year 1975 to 2001, whereas ablation area of each glacier is very much increased during 1975 to 2001.Especially in the case of small glaciers including snow/ice which number around 134 in the study area, the accumulation area has also reduced drastically from 1975 to 2001.

Mass balance is one of the important parameter which is influenced by global warming. Mass balance is usually referred to as a total loss or gain in glacier mass at the end of the hydrological year (Heilskanen et al., 2002). Though in the years 1975 and 1992, there is positive specific mass balance but in the year 2001, specific mass balance of all glaciers was negative.

\section{Conclusions}

It can be summarized that inventory of the glaciers is of prime interest to evaluate the nature of changes in glacier dimensions and also to establish relationship between climatic change and dynamics of glaciers. As per glacier inventory based on satellite images of September 1975, 1992 and 2001, 13 major glaciers have been chosen for the detailed study in the study area. Total area loss of glaciers from 1962 to 2001 is $18.16 \%$. The glacier G5 and G3 showed $30.48 \%$ and $28.91 \%$ of the area loss respectively. It is estimated that during last 40 years (1962-2001) majority of glaciers has been retreated. Highest retreat is recorded along $\mathrm{G} 2(1.3 \mathrm{~km})$ and G12 $(0.93 \mathrm{~km})$ glacier whereas lowest retreat is recorded along G6 $(0.24 \mathrm{~km}), \mathrm{G} 9(0.56 \mathrm{~km})$ and G10 glacier $(0.55 \mathrm{~km})$. It is to remark that smaller glaciers are retreating at lower pace as compared large glaciers. Most of the glacier snouts are mainly located at more than $4000 \mathrm{~m}$. There is general recession of snouts of all the 13 glaciers to various distances. Though in the years 1975 and 1992, there is positive specific mass balance but in the year 2001, specific mass balance of all glaciers was negative above msl.

\section{Acknowledgements}

The authors express gratitude to Space Applications Centre, ISRO, Ahmedabad for sanctioning a project under which this work was carried out. First author wish to express his heartfelt thanks to Professor K.N.P.Raju, Department of Geography, Banaras Hindu University, Varanasi, India for his kind help in improving the text.

\section{REFERENCES}

[1] Bahuguna, I. M., Rathore, B. P., Negi, H. S., Kulkarni, A. V. and Mathur, P. (2003): Fusion of panchromatic and multispectral Indian remote sensing satellite images for identification of Gangotri glacier snout. Geological Survey of India Special Publication.

[2] Bolch T., Kamp U. (2005): Glacier Mapping in High 
Mountains Using DEMs, Landsat and ASTER Data, 8th International Symposium on High Mountain Remote Sensing Cartography, La Paz, Bolivia.

[3] Dhobal, D. P., Gergan, J. T. and Thayyen, R. J. (1999): Recession of Dokriani Glacier Garhwal Himalaya - An overview, Abstr. Symposium on now, Ice and Glaciers: A Himalayan Perspective, pp. 30-33.

[4] Dozier, J., and Hall, D. (1987): Snow mapping and classification from Landsat Thematic Mapper data. Annals of Glaciology, 9, pp. 97-103.

[5] Heilskanen, J., Kajuutti, K. and Pellikka, P. 2002: Assessment of Glaciological Parameters using Landsat Satellite Data in Svartisen, Northern Norway, Proceedings of EARSEL-LISSIG-Workshop Observing our Cryosphere from Space, Bern, March 11-13.

[6] Kulkarni, A.V. 1992: Mass balance of Himalayan Glacier using AAR and ELA method.Journal of Glaciology, 38, 101-104.

[7] Kulkarni, A. V., Rathore, B. P. and Alex, S. (2004): Monitoring of glacial mass balance in the Baspa basin using accumulation area ratio method. Curr. Sci., 86, pp. 101-106.
[8] Kulkarni, A. V., Rathore, B. P., Mahajan, S. and Mathur, P. (2005): Alarming retreat ofParbati Glacier, Beas basin, Himachal Pradesh. Current Science, 88, pp. 1844-1850.

[9] Naithani, A.K., Nainwal, H.C., Sati, K.K. and Prasad, C. (2001): Geomorphological evidences of retreat of Gangotri glacier and its characteristics, Current Science, 80, 87-94.

[10] Paul, F. (1999): Changes in glacier area in Tyrol, Austria, between 1969 and 1992 derived from Landsat 5 TM and Austrian Glacier Inventory data. International Journal of Remote Sensing, 23 (4), pp. 787-799.

[11] Rai, P.K., Nathawat, M.S., Pandey, A.C., Raju, K.N.P. (2009): Morphometric characteristics of glaciers in Doda valley, Zanskar basin, J \& K, Transaction (IIG, Pune), 31 (2), 135-141.

[12] Rai, P.K., Nathawat, M.S., Mohan, K. (2012). Geo-Aspect Analysis an Area Altitude Distribution of Glaciers Doda Valley, Zanskar Basin, Jammu \& Kashmir, India, National Geographical Society of India, Vol. 58 No.4, 107-116. 